\title{
Food habits of Oligoryzomys longicaudatus (Rodentia) in a steppe-forest transitional area of Argentinean Patagonia
}

\author{
Francisco Polop ${ }^{1}$; Lorena Sepúlveda ${ }^{2}$; Alicia Pelliza Sbriller ${ }^{2}$; Jaime Polop ${ }^{1} \&$ \\ M. Cecilia Provensal ${ }^{1 \otimes}$ \\ 1. Departamento de Ciencias Naturales, Facultad de Ciencias Exactas, Físico-Químicas y Naturales, Universidad Nacional \\ de Río Cuarto, Argentina. 2. Laboratorio de Microhistología, Instituto Nacional de Tecnología Agropecuaria. Estación \\ Experimental Agropecuaria Bariloche, Argentina.
}

\begin{abstract}
Aвstract. We described the spatial and seasonal variation of feeding habits of Oligoryzomys longicaudatus in four environments of the steppe-forest transition zone of Argentinean Patagonia. Composition of fecal pellets collected from live-trap captures was determined with microhistological techniques using an identification key of representative plants of our study areas. Fruits and seeds constituted $57.2 \%$ of O. longicaudatus diets, followed by foliage $(26.8 \%)$ and arthropods $(16.0 \%)$. Fruits and seeds, foliage parts, and arthropods were primarily found in individuals from shrublands, forests, and peridomestic areas, whereas foliage predominated in pastures. Similarity index revealed differences between pastures and the other environments. Diet in shrubland showed differences among seasons, but not among years. Fruits of Rosa spp. constituted the main food consumed in shrubland, forest and peridomestic environments mainly in autumn and winter, whereas in spring and summer high proportions of arthropods and other items were eaten. Thus, O. longicaudatus could be described as frugivorous in this region, explained by an opportunistic behavior and the spatial variation of available resources.
\end{abstract}

[Keywords: Diet, spatial variation, temporal variation, frugivorous, opportunism, reservoir of Andes genotype hantavirus]

\begin{abstract}
Resumen. Hábitos alimentarios de Oligoryzomys longicaudatus (Rodentia) en un área de transición bosqueestepa de la Patagonia Argentina: Describimos la variación espacial y temporal de los hábitos alimentarios de Oligoryzomys longicaudatus en cuatro ambientes de un área de transición bosque-estepa en la Patagonia argentina. La composición de las heces de los roedores, colectadas en las trampas de captura viva, fue determinada con técnicas microhistológicas, utilizando una clave de identificación de plantas representativas en las áreas de estudio. Los frutos y las semillas constituyeron el $57,2 \%$ de la dieta de O. longicaudatus, seguidas por partes vegetativas $(26,8 \%)$ y artrópodos (16\%). En las heces de individuos capturados en matorrales, bosques y hábitats peridomésticos se encontraron principalmente frutos y semillas, partes vegetativas y artrópodos, mientras que las partes vegetativas predominaron en las de pastizales. Los índices de similitud revelaron esas diferencias entre las dietas en los pastizales y en el resto de los hábitats. La dieta de los individuos capturados en matorrales mostró leves diferencias entre estaciones, pero no entre años. Los frutos de la Rosa spp. constituyeron el principal alimento, fundamentalmente en otoño e invierno, mientras que en primavera y verano consumieron altos porcentajes de artrópodos y otros ítems. Así, O. longicaudatus podría ser descripto como frugívoro en esta región, lo que se explica por un comportamiento oportunista y la variación espacial del recurso disponible.
\end{abstract}

[Palabras clave: Dieta, variación espacial, variación temporal, frugívoro, oportunismo, reservorio del hantavirus genotipo Andes]

\section{INTRODUCTION}

The sigmodontine rodent Oligoryzomys longicaudatus (Bennett 1932), commonly known as "colilargo", is one of the most abundant and wide-range species in the southwestern South America. In Argentina this rodent inhabits the east of the Andean Patagonian forest, from $30^{\circ} \mathrm{S}$ to $44^{\circ} \mathrm{S}$ (Porcasi et al. 2005; Carbajo \& Pardiñas 2007). In this area O. longicaudatus shows a marked habitat amplitude (Murúa \& González 1982; Pearson \& Pearson 1982; Pearson 1983, 2002; Monjeau et al. 1998; González et al. 2000; Pardiñas et

Editor asociado: Fernando Milesi

$\bowtie$ cprovensal@exa.unrc.edu.ar al. 2000, 2003; Torres Perez et al. 2004; Piudo et al. 2005; Polop et al. 2010), with the highest number of captures in forest and shrublands and the lowest in the steppe (Cantoni et al. 2001; Larrieu et al. 2003; Piudo et al. 2005; Polop et al. 2010). Those differences have been mostly associated to foliage density and thick understory (Murúa \& Gonzalez 1982; Kelt et al. 1994; Kelt 2000; Gonzalez et al. 2000) and to shrub cover and presence of spiny shrubs (Lozada et al. 2000). In addition, differences in abundance were associated with food availability and quality, suggesting that they are the main limiting factors of

Recibido: 19 de noviembre de 2013; Fin de arbitraje: 29 de enero de 2014; Última versión revisada: 25 de abril; Aceptado: 29 de abril. 
the reproductive period length in southern temperate forest (Murúa et al. 1986; González et al. 1989). Understanding the causes of abundance changes of $O$. longicaudatus is of epidemiologic interest, since it is a reservoir of Andes (ANDV) genotype hantavirus, related to Hantavirus Pulmonary Syndrome (HPS) in southern Argentina and Chile (López et al. 1996; Padula et al. 2000).

Most previous studies on O. longicaudatus diet have been done in the central Chile, where it has been described as granivorous (Meserve \& Glanz 1978; Murúa et al. 1980; Meserve 1981a; Murúa \& Gonzalez 1981; Pearson 1983; Meserve et al. 1988). There, seasonal differences showed higher intake of seeds during drier seasons, and flowers, foliage and occasionally arthropods included in wetter seasons. On the other hand, Muñoz Pedreros et al. (1990) characterized $O$. longicaudatus as omnivorous in a pine (Pinus radiata) plantation, although there was high consumption of seeds and fruits in spring and summer. The studies of O. longicaudatus trophic ecology showed dissimilar results, caused probably by differences in space and time scales, season and habitat, disturbance intensity and interactions with other assemblage species. The temporal variation in the resources availability is common in most terrestrial ecosystems (Ostfeld \& Keesing 2000), and the response of consumers also varies, showing that diet is not fixed but dynamic (Jaksic et al. 1993; Farías and Jaksic 2007).

There is no published data on O. longicaudatus diet in Argentina. Populations in the eastern Andean Cordillera inhabit different environmental conditions than on the Chilean side, which may affect resource availability and forage conditions (Polop et al. 2010). Our objectives were: 1 ) to describe $O$. longicaudatus diets, 2) to compare spatial variation in diets in four Patagonian environments of Argentina in the autumn, 3) to compare seasonal and annual diets in shrubland environments, and 4) to compare the most consumed item (Rosa spp.) among environments, seasons and years.

\section{Materials And Methods}

\section{Study area}

The study was carried out seasonally from summer 2004 to spring 2006 in Cholila ( $42^{\circ} 31^{\prime} S$; $71^{\circ} 27^{\prime} \mathrm{W}$ ), Andean region, Chubut Province, Argentina. The study area is a steppe-forest transition zone described in Polop et al. (2010).
Trapping was conducted in four representative environments: shrublands, forests, pastures and peridomestic areas. Shrublands were characterized by native woody species such as Berberis buxifolia, Acanthostyles buniifolius, Rhamnus lycioides, Ribes spp., Schinus patagonicus, Discaria trinervis, Discaria articulata, Fabiana imbrincata, Escallonia virgata, in variable proportions, and the non-native species (Rosa spp.) covering up to $70 \%$ of the surface in some sectors (Andreo et al. 2012). Forests were dominated by native trees such as Nothofagus antarctica, N. dombeyi, Austrocedrus chilensis in low numbers, and N. pumilio (at $1200 \mathrm{~m}$ sea level), with or without Chusquea culeou in the understory. Pastures were defined as environment where the vegetation did not exceed $50 \mathrm{~cm}$ in height and were dominated by gramineous plants, with predominance of Stipa speciosa, S. humilis, Festuca pallescens, Bromus setifolius, Hordeum spp., Poa lanuginosa, Matricaria recutita, Oenothera odorata and Verbascum thapsus. Some shrub-like species may be present, such as Acaena splendens, Mulinum spinosum, Azorella monanthos and Nassauvia glomerulosa. Crop fields (e.g. alfalfa, sorghum) used as fodder for cattle and sheep and Rosa spp. are present at peripheral borders. Peridomestic areas included environments with some human use around houses; vegetation was mostly grasses, exotic species (predominating Rosa spp.) and some native shrub species.

Fruits were much more abundant in shrubland and forest than in pastures and peridomestic environments. The exotic shrub Rosa spp., in particular, occupies important areas of shrubland (up to $70 \%$ in some sectors), is frequent in forest and peridomestic environments, and scarce in pastures, where it may be present at some field borders. Fruit availability is bigger in summer and autumn, but some fruit (e.g., Rosa spp.) may be available too in winter on the plants or on the ground. Arthropods are much more abundant in summer in all environments. Pastures offer much more foliage (mostly grasses) but scarce wood and fleshy fruit.

\section{Fecal collection, analysis and quantification}

Fecal samples were obtained from individuals at the time of capture. Fifteen removing lines were placed in shrubland and 24 in each of the other three environments (forest, pasture and peridomestic). In shrublands each line had 20 live traps, while in other environments 10 live traps by line were used. Traps were placed at $10 \mathrm{~m}$ intervals. The minimum distance between trapping lines was $200 \mathrm{~m}$. The trapping was done for three consecutive nights, once during each season (spring, summer, autumn and winter). The total number of trap-nights was 39,780 (3,060 trap-nights by season). Three $10 \times 10$ capture-marked and released (CMR) grids were also placed in shrublands, consisting of 100 live traps at $10-\mathrm{m}$ intervals were also placed, from summer 2006 to summer 2007. Traps were baited with mixture of peanut butter and cow fat. The complete fecal sample from each animal at their initial capture was processed. 
Feces were fixed in ethyl alcohol at $70 \%$ and treated with gamma radiation to eliminate any potential infection risk of Hantavirus. Diet composition was determined by a microhistological analysis of fecal pellets pool of each animal, following a slight modification of Peña Neira (1980) methodology. Histological features of epidermis of leaves, seeds, fruits, roots and stems, fungi and morphological features of arthropods body parts were identified and noted down. Arthropods were identified at the taxon Class because we did not have a complete reference collection.

Table 1. Frequency of occurrence, expressed in percentage, of each food item identified in each general category, by environment, analyzed from feces of Oligoryzomys longicaudatus individuals captured from Summer 2004 to Summer 2007 (Cholila, Chubut, Argentina). Sample size is shown between brackets.

Tabla 1. Frecuencia de ocurrencia, expresado en porcentaje, de cada ítem alimentario identificado en cada categoría general, por hábitat, analizado de las heces de individuos de Oligoryzomys longicaudatus capturados desde Verano 2004 a Verano 2007 (Cholila, Chubut, Argentina). Los tamaños muestrales se presentan entre paréntesis.

\begin{tabular}{|c|c|c|c|c|}
\hline $\begin{array}{l}\text { Environment } \\
\text { Items }\end{array}$ & $\begin{array}{c}\text { Shrublands } \\
\text { (129) }\end{array}$ & $\begin{array}{c}\text { Forests } \\
\text { (53) }\end{array}$ & $\begin{array}{c}\text { Pastures } \\
\text { (11) }\end{array}$ & $\begin{array}{l}\text { Peridomestic } \\
\text { (12) }\end{array}$ \\
\hline \multicolumn{5}{|l|}{ Foliage } \\
\hline Acaena spp. & 0.00 & 0.01 & 2.73 & 0.00 \\
\hline $\begin{array}{l}\text { Achilea } \\
\text { millefolium }\end{array}$ & 3.29 & 0.10 & 0.00 & 0.00 \\
\hline Bromus spp. & 0.46 & 0.17 & 0.00 & 0.00 \\
\hline Cerastium spp. & 1.67 & 2.94 & 0.00 & 0.00 \\
\hline Crepis spp. & 0.26 & 1.05 & 0.00 & 0.00 \\
\hline Erigeron spp. & 0.01 & 0.02 & 0.00 & 0.00 \\
\hline $\begin{array}{l}\text { Erodium } \\
\text { cicutarium }\end{array}$ & 0.05 & 0.21 & 0.00 & 0.00 \\
\hline Holcus spp. & 0.49 & 0.00 & 0.68 & 0.00 \\
\hline $\begin{array}{l}\text { Hypocheris } \\
\text { spp. }\end{array}$ & 0.05 & 0.14 & 0.00 & 4.36 \\
\hline Juncus spp. & 0.01 & 0.02 & 0.00 & 0.00 \\
\hline $\begin{array}{l}\text { Osmorhiza } \\
\text { spp. }\end{array}$ & 0.10 & 0.01 & 0.00 & 0.00 \\
\hline Phleum spp. & 0.03 & 6.56 & 0.00 & 0.00 \\
\hline Plantago spp. & 0.49 & 0.02 & 0.00 & 0.00 \\
\hline Poa spp. & 1.24 & 0.00 & 22.60 & 2.39 \\
\hline Samolus spp. & 0.02 & 0.02 & 0.00 & 0.00 \\
\hline Veronica spp. & 0.02 & 0.13 & 1.75 & 0.00 \\
\hline Other Dicots & 0.04 & 0.00 & 0.00 & 0.31 \\
\hline Other Grasses & 0.34 & 1.21 & 7.47 & 1.36 \\
\hline Herbs & 1.42 & 0.20 & 3.70 & 3.24 \\
\hline $\begin{array}{l}\text { Other } \\
\text { Monocots }\end{array}$ & 0.01 & 3.58 & 5.46 & 0.00 \\
\hline Moss & 0.01 & 0.01 & 0.00 & 0.00 \\
\hline Total & 10.01 & 16.40 & 44.39 & 11.66 \\
\hline \multicolumn{5}{|l|}{$\begin{array}{l}\text { Fruits and } \\
\text { seeds }\end{array}$} \\
\hline $\begin{array}{l}\text { Maytenus fr } \\
\text { Nothofaous } f r\end{array}$ & $\begin{array}{l}0.44 \\
0.53\end{array}$ & $\begin{array}{c}0.00 \\
11.32\end{array}$ & $\begin{array}{l}1.43 \\
0.17\end{array}$ & $\begin{array}{l}0.57 \\
0.00\end{array}$ \\
\hline Rosa spp. & 70.36 & 44.81 & 8.19 & 61.58 \\
\hline Taraxacum fr & 0.02 & 0.58 & 0.00 & 0.00 \\
\hline Gramineous fr & 0.42 & 0.31 & 24.32 & 2.11 \\
\hline Flower & 0.81 & 1.75 & 0.00 & 0.07 \\
\hline $\begin{array}{l}\text { Grains and } \\
\text { seeds }\end{array}$ & 0.16 & 0.75 & 8.87 & 0.00 \\
\hline Total & 72.74 & 59.52 & 42.98 & 64.33 \\
\hline Arthropods & 12.70 & 19.84 & 9.97 & 23.63 \\
\hline
\end{tabular}

Tissues of all plant species recorded in the collected feces were finely ground and mounted on microscope slides. Color photographs of reference slides served as identification key of plant fragments in the fecal pellet samples. Considering general affinity (Luiselli 2006), food items were grouped into the following categories: foliage, fruits-seeds, and arthropods. Thus, O. longicaudatus may be classified as herbivorous, granivorous, etc, based on the types of food eaten and the relative amounts of each food type consumed (Kerley \& Whitford 1994). Considering close affinity (Luiselli 2006), food items were distinguished at genus and/or species level or at other taxonomic category.

Ninety six microscope fields ( $16 \times 6$ finding on the cover glass) were systematically examined in each slide under a microscope at 100 power magnifications using a binocular microscope. The presence of each recognizable item in each field was recorded. Total and seasonal percentages describing $O$. longicaudatus diet by environment were based on the mean percentage obtained from items composition of the fecal analysis. Percent composition of each food item was determined for each slide (Holechek \& Gross 1982). These percent compositions were averaged for all feces collected from each individual captured in each environment during the same sampling period, providing a mean value for each plant species. Only percent composition values equal to or greater than $5.0 \%$ in one environment and season, or registered at least in three seasons or in two environments were considered. For this analysis, occurrence $(\mathrm{O})$ by environment and season was calculated as the number of individuals that consumed a particular item $(i)$ over the total number of individuals analyzed.

Similarity indices were used to compare diet compositions of $O$. longicaudatus between seasons, years and environments using the Ov index (Pianka 1973). Comparisons of O. longicaudatus diets between environments were done considering samples from capture lines of autumn 2004 2005 and 2006 altogether. We could only include peridomestic environment in those comparisons in autumn 2005 due to small sample sizes.On the other hand, only the abundance of Rosa spp. was comparable among environment, season and years using ANOVA and Tukey tests, when the assumptions of normality and homogeneity of variance were accomplished.

\section{RESULTS}

Three hundred sixty two O. longicaudatus feces samples were analyzed: 286 from shrublands (129 from capture lines and 157 from grids), 53 from forests, 11 from pastures and 12 from peridomestic areas.

Data obtained from sample lines (grouping every year, season and environment data), showed that fruits and seeds constituted 
$57.2 \%$ of $\mathrm{O}$. longicaudatus diet occurring in $72.4 \%$ of the individuals; followed by foliage (26.8\%), occurring in $79.5 \%$ of individuals, and arthropods $(16.0 \%)$ in $40.4 \%$ of the individuals. Regarding diet composition by environment, fruits and seeds were the most frequent items found in shrubland, forest and peridomestic environments, whereas foliage prevailed in pasture (Table 1). Arthropods occurred in $54 \%$ of individuals captured in shrubland and forests and a minor percentage in pasture and peridomestic environments.

Only twenty food items identified at genus level and nine identified at other taxonomic category were considered for forthcoming analyses (Table 1). Unidentified items plus those that did not reach $5 \%$ of frequency value constituted $3 \%$ of total diet. Thus, 28 items were identified in shrubland, 24 in forest, 13 in pasture and 10 in peridomestic environments (Table 1).

Rosa spp. fruit was recorded in a high percentage of occurrences. It represented $76.8 \%$ of items recorded in $84.4 \%$ of feces analyzed. In shrubland environments $95.8 \%$ of fruit item corresponded to Rosa spp., occurring in $92 \%$ of individuals analyzed. In peridomestic environment $93.8 \%$ of recorded fruits were also Rosa spp., whereas the lowest percentages were from individuals in pastures.

Diets between shrubland and forest had high similarity $(\mathrm{Ov}=0.97)$; whereas diets in shrubland vs. pasture and in forest vs. pasture were very different $(0.05$ and 0.10 respectively), considering autumn 2004, 2005 and 2006 together. Unidentified grasses,

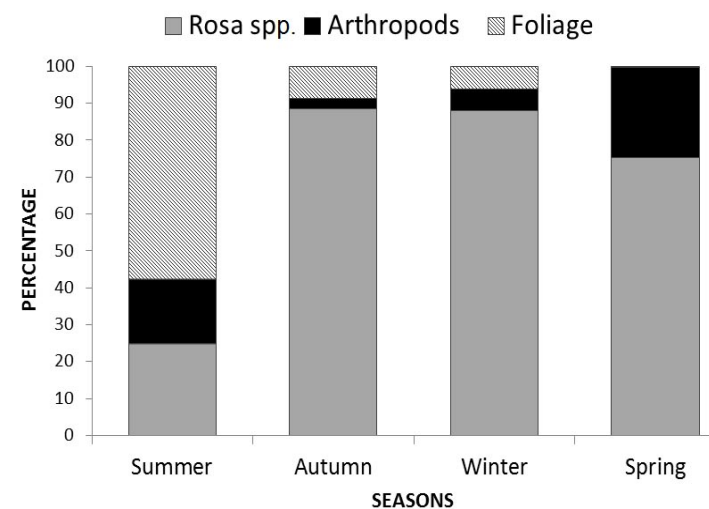

Figure 1. Seasonal diet composition of Oligoryzomys longicaudatus in shrubland environment (Summer 2004-Summer 2007, Cholila, Chubut).

Figura 1. Composición estacional de la dieta de Oligoryzomys longicaudatus en ambiente de Matorral (Verano 2004-Verano 2007, Cholila, Chubut).
Table 2. Similarity of Oligoryzomys longicaudatus diet composition between seasons (Summer: 2004, 2006; Autumn: 2004, 2005, 2006; Winter and Spring: 2004, 2005) according to OV index (Pianka 1973), in shrubland environments (Cholila, Chubut, Argentina)

Tabla 2. Similitud de la composición de la dieta por el índice OV (Pianka 1973) de Oligoryzomys longicaudatus entre estaciones (Verano: 2004, 2006; Otoño: 2004, 2005, 2006; Invierno y Primavera: 2004, 2005), en ambientes de matorral (Cholila, Chubut, Argentina).

\begin{tabular}{lccc}
\hline Seasons & Summer & Autumn & Winter \\
\hline Autumn & 0.64 & & \\
Winter & 0.61 & 0.99 & \\
Spring & 0.67 & 0.95 & 0.96 \\
\hline
\end{tabular}

arthropods, Poa spp. and unidentified grass fruits were the most frequent recorded items in pasture. In shrubland, and forest diets of years 2004, 2005 and 2006 were constituted mainly by Rosa spp. and arthropods, showing Rosa spp. significant differences between those environments $\left(F_{1,101}=4.31, p=0.04\right)$, being higher in shrubland (51.5\%) than in forest (36.7\%). Considering only autumn 2005, the diet between peridomestic environments and shrubland had also high similarity $(\mathrm{Ov}=$ 0.96), followed by forest vs peridomestic environments (0.75). Pasture and peridomestic environments showed the lowest similarity (0.21).

In shrubland envrionment, comparisons of diet composition between years showed high similarity values (2004 vs. 2005: Ov $=0.99$; 2004 vs. 2006 and 2005 vs. 2006: Ov = 0.96). Comparisons between seasons in shrubland, showed that summer had the lowest similarity to the other seasons, whereas the other seasons showed high similarity among themselves (Table 2). Summer diet was more diverse, with lower records of Rosa spp. and a high percentage of foliage and arthropods (Figure 1). Rosa spp. item (considering autumn, winter and spring together), showed significant differences among years $\left(\mathrm{F}_{2,99}=3.45, \mathrm{p}=0.03\right)$, particularly between 2004 vs. $2006(\mathrm{p}=0.006)$ and 2005 vs. $2006(\mathrm{p}=0.008)$; their occurrence was $56.99 \%$ in $2004,53.62 \%$ in 2005 and $69.85 \%$ in 2006.

\section{DISCUSSION}

According to our results, $O$. longicaudatus could be classified as frugivorous, because diet contains fruit items in more than $50 \%$ of the analyzed feces occurring in more than $70 \%$ of individuals. Our trophic characterization of O. longicaudatus does not agree with other authors from other localities. Meserve \& Glanz (1978) and Meserve (1981b), have classified 
O. longicaudatus as moderate to strongly granivorous, with a clear trophic specialization and with some opportunist dietary behavior in brushes of Chile in humid season. In contrast, Murúa et al. (1986) described this rodent as omnivorous in pine forests. Nevertheless, Silva (2005), in a bibliographic revision, acknowledged that dietary habits of $O$. longicaudatus in Chile changed significantly among localities, being characterized as granivorous-frugivorous, herbivorous and herbivorous-granivorous-frugivorous. In addition, we could also characterize $O$. longicaudatus as an opportunistic consumer.

The opportunistic behavior implies the use of food resources according to abundance (e.g. Jaksic 1989), thus we would need to quantify food resource availability. In this study there is no precise data on vegetal species availability expressed as percentages in each of the environments or seasons considered. But we have bold estimates allowing us to rank those conditions, and clearly Rosa spp. is abundant in most environments studied (Andreo et al. 2012). In this context, O. longicaudatus can be frugivorous by active food selection or because there is no better option. Considering the already reported opportunistic behavior of O. longicaudatus (Murúa et al. 1980; Meserve et al. 1988; Muñoz-Pedreros et al. 1990), it is expected to consume Rosa spp. in environments where this resource is abundant. Moreover, our results are expected to differ from others in different environments, where other resources are predominant. Our results showed that individuals consumed few items in each environment, suggesting a restricted use of those with high representation in the environment and allowing them to advantageously exploit Rosa spp., an exotic and relatively recent food resource in our study area.

Fruits of Rosa spp. mature in late summer and autumn; in late autumn and winter they reach their highest nutritive value as they are rich in sugar with high content of proteins (Somlo \& Cohen 1997) and vitamin C (Pirone et al. 2002). This food is highly palatable for $O$. longicaudatus (Pelliza \& Sepúlveda 2008). The high availability of this fruit could be associated with the final period of reproductive activity and survival of overwintering individuals to the next period. In early spring that fruit loses some nutritive conditions (Pirone et al. 2002), which may explain the lower proportions of Rosa spp. registered in a summer diet (November-January), replaced by arthropods and the incorporation of other items like fruits of Nothofagus spp and Maytenus spp, grains, unidentified herbs and unidentified grasses and bulbs. The high consumption of bulbs in summer 2006 may be consequence of the drought of this year (Polop 2011). Muñoz-Pedreros et al. (1990) and Murúa and González (1981) registered seasonal changes in O. longicaudatus diet, but they registered consumption of fruits and seeds in spring and summer and arthropods and fungi in winter.

Differences of our results respect to others could be also related to the technique to analyze stomach or fecal contents. According to Mcinnis et al. (1983), fecal analyses overestimate the less digestible portions of the diet and underestimate the more digestible portions, so the accuracy of fecal analyses could probably be enhanced by the determination of digestibility coefficients of various plant species in different phenological stages and for different animal species. It can be supposed that the representativeness of fruits of Rosa spp. in diet composition, determined by fecal analysis could have been underestimated. Nevertheless, we were able to detect high quantities of Rosa spp. fruits in spite of those methodological limitations. Furthermore, though we cannot evaluate to what extent fecal material accurately represents the actual diet of an organism, we still can trust in relative proportional or rank estimates of dietary composition rather than on absolute percentages.

Many studies of rodent abundance and distribution have emphasized the influence of environment features at fine scale like resource abundance, structural characteristics of vegetation, composition of plant species and habitat size. In our study area $O$. longicaudatus diet seems similar through the seasons (composed principally by Rosa spp.) except in summer. When we compare our results with studies of $O$. longicaudatus diet from other regions, differences appear but similarities in its characterization as an opportunistic species are also evident. Our observations allow us to characterize O. longicaudatus as food opportunistic, following the spatial variation of resource availability. Considering that (1) Rosa spp. fields are used as refuge (Polop 2011; Andreo et al. 2012), (2) that its fruits are consumed by $O$. longicaudatus in our study area, (3) that its high availability is associated with high abundances of this rodent (Andreo et al. 2012), and (4) that its fruits constitute 
an economic resource for inhabitants of the region, it becomes highly important for studies of $O$. longicaudatus population dynamics and to design preventive polices in the control of HPS disease.

ACKNOWLeDgements: This research was supported by Fundación Mundo Sano and Fondo para la Investigación Científica y Tecnológica (FONCYT). Authors thank S Vilor for the revision of English. We also thank F Milesi and two anonymous reviewers for their useful comments and suggestions on this manuscript.

\section{REFERENCES}

Andreo,V; MC Provensal; S Levis; N Pini; D EnRÍA; J Polor. 2012. Summer-autumn distribution and abundance of the hantavirus host, Oligoryzomys longicaudatus, in Northwestern Chubut, Argentina. J Mammal, 93: 15591568.

Cantoni, G; P Padula; G Calderón; J Mills; E Herrero; P SANDOVAL; ET AL. 2001. Seasonal variation in prevalence of antibody to hantaviruses in rodents from southern Argentina. Trop Med Int Health, 6:811-816.

CARbajo, AE \& UFJ PARdĩ̃As. 2007. Spatial distribution model of a hantavirus reservoir, the long-tailed colilargo (Oligoryzomys longicaudatus), in Argentina. J Mammal, 88:1555-1568

FARÍAS, AA \& FM JAKSIC. 2007. El Niño events, the lean versus fat scenario, and long-term guild dynamics of vertebrate predators in a South American semiarid ecosystem. Austral Ecol, 32:1-14.

GonzÁlez, LA; R Murúa \& C Jofré. 1989. The effect of seed availability on population density of Oryzomys in southern Chile. J Mammal, 70:401-403.

GONZÁLEZ, LA; R MurÚA \& C Jofré. 2000. Habitat utilization of two muroid species in relation to population outbreaks in southern temperate forests of Chile. Rev Chil Hist Nat, 73:489-495.

HoleCHECK, JL; BD GROSS. 1982. Evaluation of different calculation procedures for microhistological analysis. $J$ Range Manage, 35:721-723.

JAKSIC, FM. 1989. Opportunism vs selectivity among carnivorous predators that eat mammalian prey: statistical test of hypothesis. Oikos, 56:427-430.

JAKsic, FM; PL Meserve; JR Gutierrez \& EL TABILO. 1993. The components of predation on smallmammals in semiarid Chile: preliminary results. Rev Chil Hist Nat, 66: 305-321.

KELT, DA. 2000. Small mammal communities in rainforest fragments in central southern Chile. Biol Conserv, 92: 345-358.

Kelt, DA; PL Meserve \& BK Lang. 1994. Quantitative habitat associations of small mammals in a temperate rainforest in southern Chile: empirical patterns and the importance of ecological scale. J Mammal, 75:890-904.

KerLey, GIH \& WG WhitFord. 1994. Desert-dwelling small mammals as granivores: Intercontinental variations. Aust J Zool, 42:543-555.

Larrieu, E; E Herrero; M García Cachau; JL Labanchi; S Mancini; P Padula; ET AL. 2003. Seroprevalencia de hantavirus en roedores y casos humanos en el sur de Argentina. Rev Bras Epid, 6:68-75.

López, N; P Padula; C Rossi; ME LÁzaro \& MT FranzeFERNANDEZ. 1996. Genetic identification of a new hantavirus causing severe pulmonary Syndrome in
Argentina. Virology, 220:223-226.

Lozada, M; N GuthmanN; N Baccala. 2000. Microhabitat selection of five sigmodontine rodents in a forest-steppe transition zone in Northwestern Patagonia. Stud Neotrop Fauna E, 35:85-90.

LuISELLI, L. 2006. Broad geographic, taxonomic and ecological patterns of interpopulation variation in the dietary habits of snakes. Web Ecology, 6:2-16.

MCINNIS, ML; M VAVRA \& WC KRUEGER. 1983. A comparison of four methods used to determine the diets of large herbivores. J Range Manage, 36:302-306.

Meserve, PL. 1981a. Resource partitioning in a Chilean semi-arid small mammal community. J Anim Ecol, 50: 745-757.

Meserve, PL. 1981b. Trophic relationships among small mammals in a Chilean semiarid thorn scrub community. J Mammal, 62:304-314.

Meserve, PL \& WE GLANZ. 1978. Geographical ecology of small in the northern Chilean arid zone. J of Biogeographic 5:125-148.

Meserve, PL; BK Lang; BD Patterson. 1988. Trophic relationship of small mammals in a Chilean temperate rain forest. J Mammal 69:721-730.

MonJeAu, JA; EC BIRNEY; L GHERMANDI, RS SiKes; L MARGUTTI \& CJ PHILlips. 1998. Plants, small mammals, and the hierarchical landscape classifications of Patagonia. Landscape Ecol, 13:285-306.

Muñoz-Pedreros, A; R Murúa \& L GonzÁlez. 1990. Nicho ecológico de micro mamíferos en un agroecosistema forestal de Chile central. Rev Chil Hist Nat, 63:267-277.

MurúA, R; LA GONZÁLEZ. 1981. Estudios de preferencias $\mathrm{y}$ hábitos alimentarios en dos especies de roedores cricétidos. MedioAmbiente (Chile), 5:115-124.

MurúA, R \& LA GONZÁLEZ. 1982. Microhabitat selection in two Chilean cricetid rodents. Oecologia, 52:12-15.

MurúA, R; LA GonZÁLEZ \& C JofrÉ. 1980. Experimental food preferences of two southern chilean rodents. $J$ Mammal, 61:138-140.

Murúa, R; LA GonzÁlez \& PL Meserve. 1986. Population ecology of Oryzomys longicaudatus philippii (Rodentia: Cricetidae) in southern Chile. J Anim Ecol, 55:281-293.

Ostfeld, RS \& F KeEsing. 2000. Pulsed resources and community dynamics of consumers in terrestrial ecosystems. Trends Ecol Evol, 15:232-237.

Padula, PJ; SB Colavecchia; VP Martinez; MO Gonzalez Della Valle; A Edelstein; SDL Miguel; et Al. 2000. Genetic diversity, distribution, and serological features of hantavirus infection in five countries in South America. J Clin Microbiol, 38:3029-3035.

Pardiñas, UFJ; G Moreira; C García-Esponda \& LJM DE SANTIS. 2000. Deterioro ambiental y micromamíferos durante el Holoceno en el nordeste de la estepa patagónica (Argentina). Rev Chil Hist Nat, 72:541-556.

Pardiñas, UFJ; P Teta; S Cirignoli \& DH Podestá. 2003. Micromamíferos (Didelphimorphia y Rodentia) de norpatagonia extra andina, Argentina: Taxonomía alfa y biogeografía. Mast Neot, 10:69-113.

PeArson, OP. 1983. Characteristics of a mammalian fauna from forests in Patagonia, Southern Argentina. J Mammal, 64:476-492.

Pearson, OP. 2002. A perplexing outbreak of mice in Patagonia, Argentina. Stud Neotrop Fauna E, 37:187-200

Pearson, OP \& AK Pearson. 1982. Ecology and biogeography of the southern rainforests of Argentina. Special Publication Pymatuning Laboratory of Ecology, 6: 
129-142.

Pelliza, A \& L Sepúlveda. 2008. La rosa mosqueta, el colilargo patagónico y el hantavirus, Desde la Patagonia difundiendo saberes, 6:18-21. Universidad Nacional del Comahue.

Peña Neira J \& Mid De Peña. 1980. Serie técnico científica, Vol 1. $\mathrm{N}^{\circ} 6$. Instituto Nacional de Investigaciones Pecuarias. México.

PIANKA, ER. 1973. The structure of lizard communities. Annu Rev Ecol Syst, 4:53-74.

Pirone, B; M Ochoa; A Kessler \& A De Michelis. 2002. Evolución de la concentración de ácido ascórbico durante el proceso de deshidratación de frutos de la rosa mosqueta (Rosa eglanteria). RIA, 31:85-98.

Piudo, L; M Monteverde; S Gonzalez Capria; P Padula \& P CARMANChahI. 2005. Distribution and abundance of sigmodontine rodents in relation to hantavirus in Neuquén, Argentina. J Vector Ecol, 30:119-125.

Polop, FJ. 2011. Dinámica temporal del sistema virushuésped para Hantavirus en Cholila (Chubut). PhD
Thesis. Universidad Nacional de Río Cuarto, Córdoba, Argentina. 230 pp.

Polop, FJ; MC Provensal; N PinI; SC LeVIS; JW PRIOTTO; D ENRíA; ET AL. 2010. Temporal and spatial host abundance and prevalence of Andes Hantavirus in Southern Argentina. Ecohealth, 7:176-184.

Porcasi, X; GE Calderon; M Lamfri; M Scavuzzo; MS SABATtini \& JJ Polor. 2005. Predictive distribution maps of rodent reservoir species of zoonoses in Southern America. Mast Neot, 12:199-216.

SILVA, SI. 2005. Posiciones tróficas de pequeños mamíferos en Chile: una revisión. Rev chil hist nat, 78:589-599.

Somlo, R \& L Cohen. 1997. Tablas de valor nutritivo de especies forrajeras patagónicas. 1 Cordillera y Precordillera. Comunicación Técnica N5. Área de Recursos Naturales. Nutrición Animal.

Torres Perez, F; R Navarrete-Droguett; R Aldunate; TL YATES; ET AL. 2004. Peridomestic small mammals associated with confirmed cases of human hantavirus disease in southcentral Chile. Am J Trop Med Hyg, 70:305-309. 